\title{
GIS Software Based on Android Mobile to Search Tourism Objects Using Technology Acceptance Model with Rasch Model Measurement
}

\author{
M. Rudi SJY ${ }^{1^{*}}$, Dedy KURNIAWAN ${ }^{2}$, Arianysah SAPUTRA ${ }^{3}$, Novita SARI ${ }^{4}$,
}

\author{
Rahma DESTRIANI ${ }^{5}$
}

\author{
${ }^{1}$ Instrumentation and application Nanotechnology Laboratory Department of Computer, Faculty of Computer Science, \\ Universitas Sriwijaya, Indonesia \\ ${ }^{2}$ Department of Computer Engineering, Faculty of Computer Science, Universitas Sriwijaya, Indonesia \\ ${ }^{3}$ Department of Computer Engineering, Sriwijaya State Polytechnic, Indonesia \\ ${ }^{4,5}$ Student Department of Computer Engineering, Faculty of Computer Science, Universitas Sriwijaya, Indonesia \\ *Corresponding author: m.rudi.sjy@ilkom.unsri.ac.id
}

\begin{abstract}
Android is a mobile operating system used for touch screen based smart phones. The software is built using Java Android Programming language and using eclipse as the development tool. The purpose of this research is to produce a Geographic Application for tourism guidance in Palembang city consisting of tourism objects list, public places list, culinary places list and also other helpful features that can help tourists in finding information about tourism objects, public places and culinary places that display detailed information and display the location of the tourist destination. Measuring the design of this program uses the rasch measuring system consisting of the TAM tes, whereas the metrics used are TAM method (Technology Acceptance System), Perceived Usefulness (PU), Attitude Toward Use (ATU), Psychological Intention to Use (ITU), Real Application Use (ASU). The results of measuring the Rasch model using 69 respondents, to test the data using the Rasch Model The model uses 69 respondents, to test the data using the Rasch Model Testing with the Ministep application. In the aspect of reliability, for person reliability the value of 0.87 and 0.89 , produces a very good value. While for reliability items the value of 0.74 and 0.78 produces good value. while the Cronbach alpha index also produces a Cronbach Alpha value yields a value of 0.90 (produces a good value). Determination of sample size uses the Item Measure table based on the accuracy of confidence measurements $(95 \%)$.
\end{abstract}

Keywords: android, TAM, Rasch Model, GIS

\section{Introduction}

Attraction list is an application to determine the form of place names, addresses, photos, detailed information, and coordinates of locations that will be connected directly to Google Maps so that the results of the test and all functional specifications and displays show the response as expected. From a data transfer speed test is also used to show a fast and precise response, because the data accessed is not too large for this mobile application. [1] This study is used to contribute to this heterogeneous context by investigating public perticipation in GIS in the field of mobile based application. Such results show not only examples of how to create pra ctical GIS applications that enable users to gather and inte ract with geospatial data, but also those with assumptions regarding public participation approaches and needs. In one case, an open source architecture was used, which happened to allow users to exploit their android mobile devices to collect georeferenced information. This data is then publicly available to Web viewers and analysis of user involvement in the project provides insights related to participation patterns that show some conclusions.[2]
Sumenep Regency is one pf the district on madura island in a tourism sector is undergoing rapid an accurate development and improvement where sumenep regency has natural and cultural to attraction. Not only from the cultural attractions of the cattle are easy, but also Sumenep Regency which has a very beautiful natural attraction. Natural tourism condition consists of natural scenery consisting of high hills, beaches, high asta am arine potential diversity, so one popular attraction is pantai sembilan, and Gili Labak Island, Gilii with the world's best oxygen content. Toourist outside the region, particularly those who visit sumenep regency for the fisrt time, Tourist from outside the region, particularly those who visit sumenep regency for the first time, will have some diffuculty accessing tourist attractions in this city because they don't know the location of these attraction in detail. Tourist from outside the region, particulary those who visit regency for the first time, will have so me difficulty accessing tourist attraction in this city because they don't know the location of these atrractions in detail. This method that designed this GIS uses the Graph Method, by applying the shortest route search algorithm, the Dijkstra Algorithm. The expected result is that this application can help and simplify, and speed up tourists in finding and 
obtaining information about the locations of tourist attractions in Sumenep Regency.[3]

Application of Geographic Information System to promote tourism in Magelang, where geographic information on system are deployed in magelang based on android.The purpose of this system is built is to provide information about tourism locations in Magelang easily and simply and can be operated wherever the user uses an Android mobile device and the application successfully presents tourism information and the closest location from the user's position. [4]

Gunung Kidul Regency is one of the Special Region of Yogyakarta, Indonesia where the center of government is in the Wonosari District. As a city filled with interesting facilities and attractions, Gunungkidul Regency is one of the tourist destinations for domestic and foreign tourists, and therefore, Gunungkidul Regency must have supproting facilities such as guides about attractions so as to facilitate tourists who will come as well as coordinate data and description of each tourist attraction carried out by direct field survey using GPS. The next step is to build an Android-based application using the MIT App Inventor 2 software. And in the last phase, it also compares the connection speed when the application is being used on WLAN networks and also $2 \mathrm{G}$ and $3 \mathrm{G}$. This study produces a mobile GIS application system about tourism in Gunungkidul Regency which is expected to help domestic and foreign tourists when they travel there. This application displays the direction and distance to tourist objects, and general information such as public transportation routes and hotel listings.[5]

Kediri is one of the cities in the East Java region that is experiencing rapid progress in development. One that is developing is the tourism sector while the media promotion in the form of information and images of tourist attractions can not represent the real conditions of tourist attractions. This research is to promote tourism in Kediri and provide an interesting and interactive media where this media consists of Android applications using Markerless technology based on Augmented Reality. And users can see virtual attractions and real objects in the same place where this technology helps users to find out virtual travel forms. it can be concluded to increase the curiosity of tourists to visit Kediri. [5]

Semantics used for digital or virtual city models have been sufficiently supported by a variety of solutions and software, especially including desktop-based GIS applications. The cellular system on the other hand is still abandoned, but the CityGML georeferenced object has many application fields, for example, in the location-based Augmented Reality area that is popular today. The main focus is on improving implementation on mobile devices, such as smartphones, and evaluating their usefulness and performance compared to softening the web-based approach.[6]

The next paper, Questions about e-Learning Style version 8.1, has been developed in measuring the diversity of student learning styles including Asian culture and learning environments that help hybridize leading learning methods, on a Bali-based page and learning. from version 8.1 which was asked using the Rasch Measurement Model.[7]

The rapid technology used by Android-based applications that encourage people to switch and use and can make transactions for payments to Paymen Point Online Bank counters (BPOB) which is felt to be lacking so that it helps the public in transaction activities and therefore presents a technology service in the field of micropayment with devices software named PayTren application that can be used for payment of transactions in small amounts (micropayment) based on Android, which is one of the right and useful alternatives to facilitate users in making transactions or can make payments and is able to shift the type of payment at payment counters in general. The purpose of this study is used to analyze the attitudes of users of Android-based PayTren applications by using one of the Technology Acceptance Model (TAM) methods, as well as testing using regression analysis. The research benefits are as a reference for further research using the TAM method and other variables are added. The results of this study are perceived usefulness and perceived ease of use have an effect that is categorized as strong and weak towards (attitude toward using) where the user's attitude.[8]

Technology is as a user's willingness to carry out tasks designed to be supported. The first Technology Acceptance Model (TAM) was introduced by Davis in 1986 and this study was used to analyze the factors that influence the receipt of Information Systems in Finance for Local Government (SIPKD) using the Technology Acceptance Model (TAM). This TAM states that behavioral interest in using Information Systems applications is determined by two beliefs consisting of: perceptions of usefulness (POU) and perceptions of ease of use (PEU) where Perception of usefulness (POU) is defined as the extent to which people believe that the use of a system will improve its performance. This TAM considers perceptions of ease of use and usability as a major factor influencing the level of acceptance of any technology. TAM is a model for explaining and predicting the use of information systems in libraries. The TAM model is used to determine user attitudes toward technology acceptance.[9]. Limitation of research to build a GIS software consisting of tourism objects list, public places list, culinary places list are used to find and facilitate tourists to visit the city of Palembang, especially to find tourist objects using java android programming language and testing respondents using Rasch model measurements. GIS (Geographic Information System)

Mobile GIS applications have received attention as well as a variety of potential target applications consisting of e-education and field research. This geospatial application used that operates on a mobile device is used enabling the visualization and editing of widely used geospatial data and formats. As well as open source mobile geospatial applications that seek to reach new potential users that emerge from the Android platform.

The core function of the prototype relies on the gvSIGMobile module along with a user interface specifically designed for the Android platform, which allows mobile users to retrieve, visualize, navigate, and modify local and remote geospatial layers. Future extensions can be used to provide missing functionality such as Location-Based Services and data sharing.[10]

\section{TECHNOLOGY ACCEPTANCE MODEL(TAM)}

Technology Acceptance Model (TAM) is a model of acceptance technology to be used by technology users. In formulate TAM, Davis uses TRA as its grand theory but does not accommodate all components of the TRA theory. Davis only made use of the components of 'Belief ' and 
Attitude "alone, while Normative Belief and Subjective Norms were not used.

The acceptance rate of information technology Acceptance is determined by the factors that are user perception to ease in using technology (Perceived Ease of Use), perception of user to benefit/usability Technology (Perceived Usefulness), user attitudes towards the use of technology (Attitude Toward Using), behavioral Intention, and actual Usage.[11] The schematic of TAM theory can be seen in the following figure 1 :

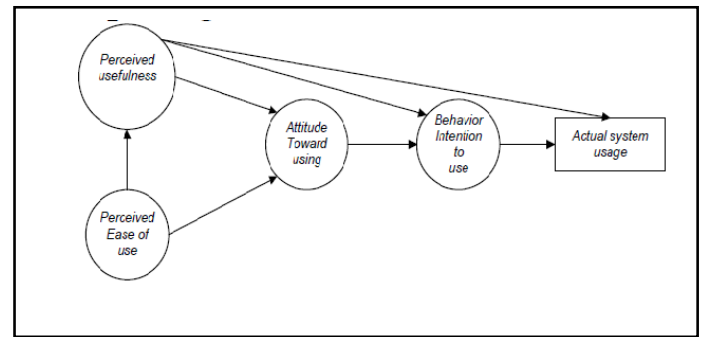

Figure 1. Technology Acceptance Model (TAM).

\section{Data Source}

Source of the data required in this study were retreived from the visitor sights of Palembang City.

\section{Data Description}

The main data required in the development of this system are:

1) Tourism Data: is data that contains a detailed description of tourism specifications consisting of a list of attractions, public places, transportation, and culinary places, plus the help feature.

2) Map: a map of tourist locations of each category that already exists and is used as a direction.

\section{System development methodology}

In developing this system design, researchers used the Prototype method. Prototype Model is one method that is widely used in software development. With this prototyping method, developers and customers can interact with each other during the system creation process.

There are often cases where a customer only defines generally what is needed. On the other hand, the developers pay less attention to algorithmic efficiency, operating system capabilities and interfaces.

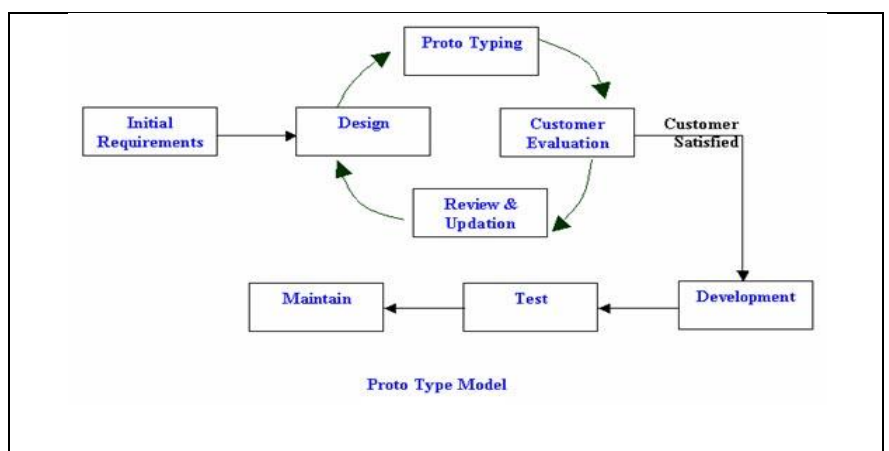

Figure 2. Prototype Model

\section{Use case Admin}

Use case Admin is an admin who can manage and access data, can delete data, edit and add data.

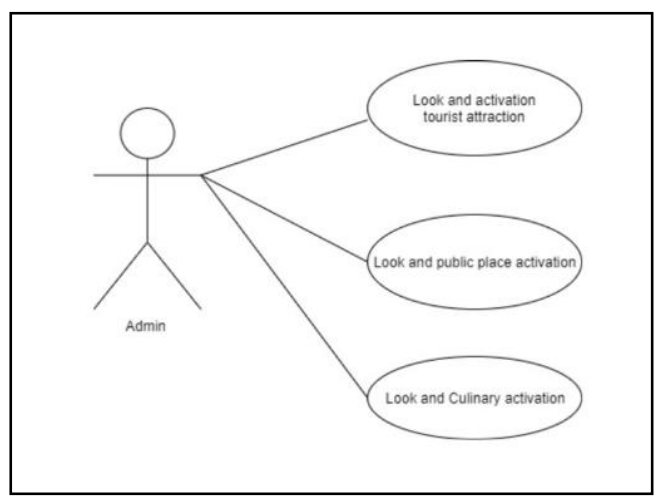

Figure 3. Use case Admin

The figure above explains the use case design for the admin, the admin can see and activate (manage data) consisting of tourism objects, public places and culinary places.

\section{Use case User}

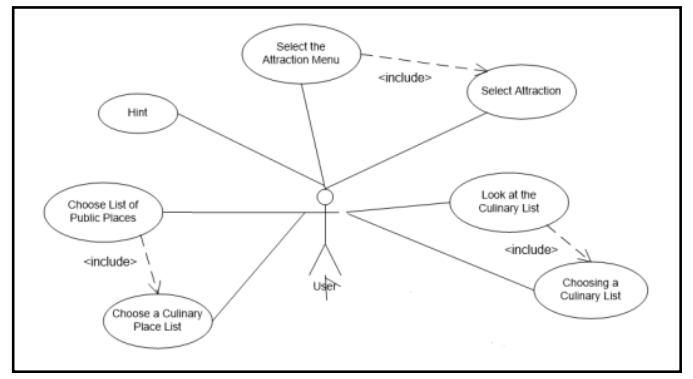

Figure 4. Use case user

In the figure above that the user can only see the menu selection of tourist objects, general tourism and culinary tourism, then select the tourist attraction then it will display all the attractions of Palembang City, after that the details of the tourism object then display a map, and so is the place general and culinary tourism.

\section{Class Diagram}

This below is a class diagram drawing to build a software.

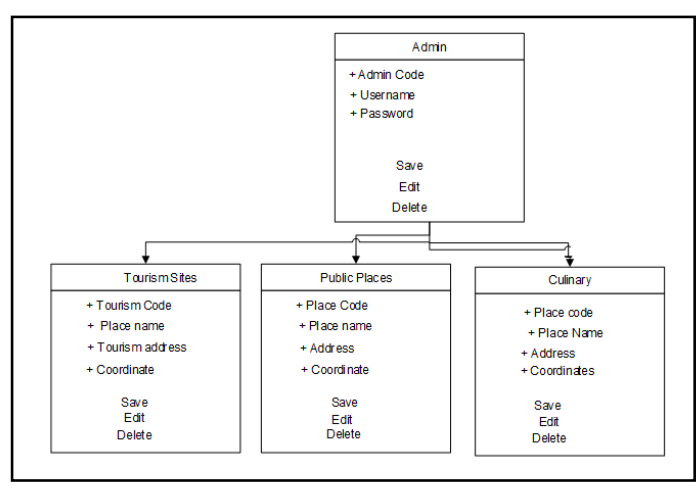

Figure 5. class diagram 
Figure 5 above explains the class diagram, which consists of admin, admin consists of username, password and has a save, edit and delete buttons. Tourism sites consist of tourism code, place name, tourism address, and coordinate and have a save, edit, delete button. Public places consist of place code, place name, address, coordinate and have save, edit and delete buttons. while the culinary place consists of code, name, coordinate and has save, edit and delete buttons.

\section{RESULTS}

Display about the login men as shown in Figure 6 where there are two software that applies as an admin

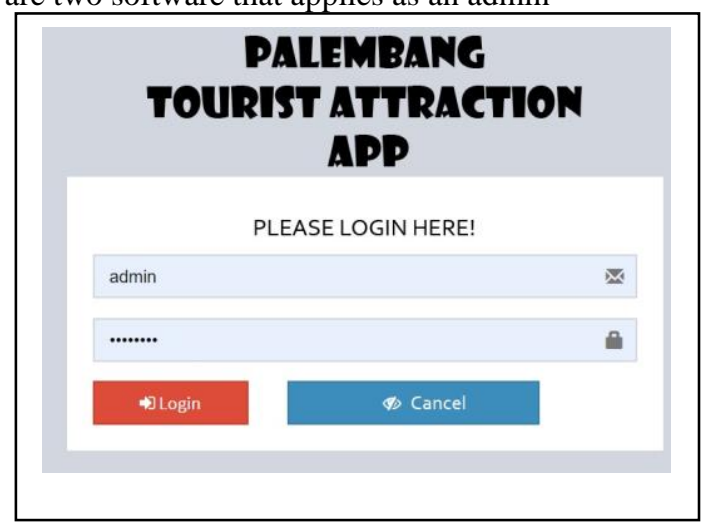

Figure 6. Main menu admin

Based on Figure 5 the main menu for the admin login to manage GIS software that is connected to the android mobile application used by the user on the smartphone

\section{Main menu User}

Display of Main GIS menu software based on Android mobile on smartphones using Android

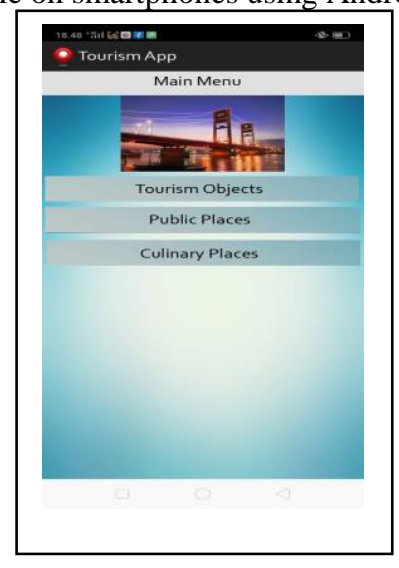

Figure 7 Menu Page

Figure 7 Menu Page Based on figure 7 is the selection of menu consists of tourism objects, public places list, transportations list, and culinary places list

\section{Display of Tourism Sites in Details}

Displays information in detail based on Android used on SmartPohone

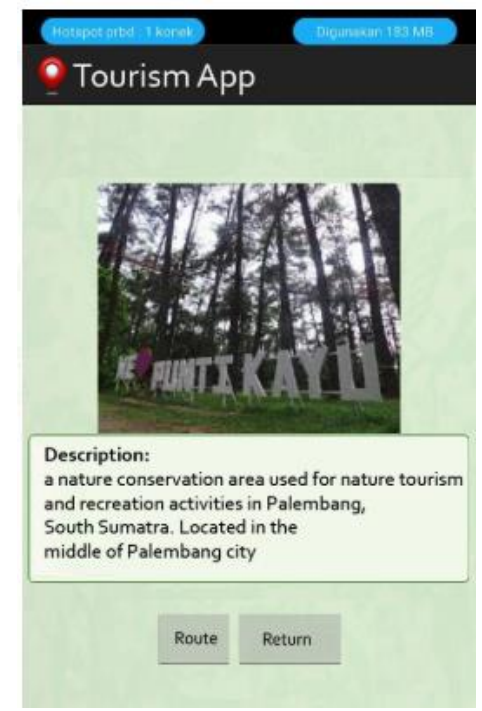

Figure 8. Detailed Information About Tourism Sites

Display detailed information related to attractions in the city of Palembang. When accessing the detailed list on the application, it will display a page in the form of tourist information and navigation of a place as in the design

\section{Rasch Model Measurement}

Data is taken from a tourist attraction that visits the tourist site directly conducts field observations of the tourist attraction, then tests the data using the Rasch testing model. The number of respondents in this study were 69 people from the general public. The Rasch Model testing uses 69 respondents, to test the data using the Rasch Model Testing with the Ministep application. The following uses the Rasch model testing using figure 10 Item Measure :

\begin{tabular}{|c|c|c|c|c|c|c|c|c|c|c|c|c|c|}
\hline \begin{tabular}{|l|l|}
$\mid$ ENTRY \\
|NUMBER
\end{tabular} & $\begin{array}{l}\text { TOTAL } \\
\text { SCORE }\end{array}$ & $\begin{array}{l}\text { TOTAL } \\
\text { COUNT }\end{array}$ & MEASURE & $\begin{array}{l}\text { MOOEL } \\
\text { S.E. }\end{array}$ & IMNSQ & $\begin{array}{l}\text { NFIT } \\
\text { ZSTD }\end{array}$ & $\begin{array}{l}\text { out } \\
\text { so }\end{array}$ & $\begin{array}{l}\text { TFIT } \\
\text { ZSTDI }\end{array}$ & \begin{tabular}{|l|} 
|PTMEAS \\
|CORRR.
\end{tabular} & $\begin{array}{l}\text { UR-AL L } \\
\text { EXP. }\end{array}$ & $\begin{array}{c}\text { EXACT } \\
\text { OBS\% }\end{array}$ & $\begin{array}{r}\text { MATCH } \\
\text { EXP\%| }\end{array}$ & Item \\
\hline 4 & 202 & 69 & 1.44 & 29 & .95 & -15 & 1.19 & 781 & .58 & 67 & 80.3 & 78.31 & ( \\
\hline 6 & 203 & 69 & 1.35 & $.30 \mid$ & 1.20 & .97| & 1.37 & 1.38 & .58 & $.67 \mid$ & 77.3 & $78.9 \mid$ & EF2 \\
\hline 7 & 208 & 69 & .89 & .31| & 1.24 & $1.05 \mid$ & 1.30 & 1.08 & .64 & $.67 \mid$ & 75.8 & $80.9 \mid$ & EF3 \\
\hline 2 & 210 & 69 & .69 & .32 & | .66 & -1.56 & .72 & $-.99 \mid$ & $\begin{array}{l}\mid 75 \\
\end{array}$ & $.67 \mid$ & 90.9 & 81.2 & \\
\hline 12 & 212 & 69 & .49 & .32 & I.73 & -1.19 & .65 & -1.28 & | .63 & $.67 \mid$ & 81.8 & 81.6 & ME4 \\
\hline 18 & 212 & 69 & .49 & $.32 \mid$ & .75 & -1.09 & .71 & -1.00 & .66 & .67 & 81.8 & 81.6 & ST2 \\
\hline 11 & 214 & 69 & .29 & .32 & .58 & -2.01 & .40 & $-2.54 \mid$ & .80 & $.67 \mid$ & 87.9 & 81.9 & MES \\
\hline 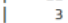 & 215 & 69 & .18 & .32 & 1.17 & .75 & 1.12 & .48 & .69 & .67 & 75.8 & 82.0 & 13 \\
\hline 10 & 215 & 69 & .18 & .32 & .45 & $-2.91 \mid$ & .37 & \begin{tabular}{|l}
$\mid .40$ \\
-2.72
\end{tabular} & .73 & .67 & 93.9 & 82.0 & ME2 \\
\hline 20 & 216 & 69 & .08 & .32 & $\begin{array}{l}1.43 \\
1.40\end{array}$ & 1.61 & 1.49 & 1.53 & .64 & .67 & 71.2 & $81.9 \mid$ & ST4 \\
\hline 15 & 218 & 69 & -.13 & .32 & & 1.91 & 1.69 & 2.01 & .57 & .67 & 81.8 & 81.6 & ER3 \\
\hline 16 & 218 & 69 & -.13 & .32 & $\mid .74$ & -1.16 & .63 & $-1.31 \mid$ & .67 & $.67 \mid$ & $\begin{array}{l}81.0 \\
89.4\end{array}$ & 81.6 & ER4 \\
\hline $\begin{array}{l}19 \\
19\end{array}$ & 218 & 69 & -.13 & $.32 \mid$ & 11.43 & $\begin{array}{r}1.10 \\
1.72 \mid\end{array}$ & 1.47 & $\begin{array}{r}-1.31 \\
1.48\end{array}$ & .78 & $.67 \mid$ & $\begin{array}{l}89.4 \\
68.2\end{array}$ & $\begin{array}{l}81.6 \mid \\
81.6\end{array}$ & 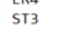 \\
\hline 8 & 220 & 69 & -.34 & .32 & 1.62 & 2.38 & 1.17 & .64 & .52 & .66 & 81.8 & 81.3 & EF4 \\
\hline 5 & 223 & 69 & -.66 & $.32 \mid$ & .71 & -1.40 & .65 & $-1.30 \mid$ & $\begin{array}{l}.72 \\
\end{array}$ & .66 & $\begin{array}{l}84.8 \\
84.8\end{array}$ & $80.9 \mid$ & EF1 \\
\hline 13 & 224 & 69 & -.76 & .32 & & 1.59 & 1.40 & 1.33 & .66 & .65 & 75.8 & $\begin{array}{l}80.91 \\
80.7\end{array}$ & ER1 \\
\hline 17 & 224 & 69 & -.76 & .32 & & 1.08 & 1.10 & .42 & \begin{tabular}{|l}
$\mid .68$ \\
\end{tabular} & .65 & $\begin{array}{l}78.8 \\
\end{array}$ & $80.7 \mid$ & ST1 \\
\hline 9 & 225 & 69 & -.86 & .32 & $\begin{array}{l}.89 \\
\end{array}$ & -.46 & .77 & $-.77 \mid$ & \begin{tabular}{|l}
.69 \\
\end{tabular} & .65 & 80.3 & 80.4 & ME1 \\
\hline 1 & 226 & 69 & -.96 & .32 & .48 & -3.06 & .43 & -2.50 & .78 & .65 & 92.4 & 80.1 & 11 \\
\hline 14 & 230 & 69 & -1.35 & $.31 \mid$ & . .70 & -1.70 & .67 & -1.28 & $\begin{array}{l}.75 \\
\end{array}$ & .63 & 89.4 & 78.8 & ER2 \\
\hline & 6 & & & & & & & 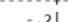 & & & 10 & (1) & \\
\hline & 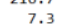 & .0 & .74 & .01 & .35 & 1.6 & .40 & 1.51 & & & 6.9 & $\begin{array}{r}1.1 \mid \\
1.0\end{array}$ & \\
\hline
\end{tabular}

Figure 10. Item Measure

In Figure 10 explain in the total count column reads is the participant answers all the questions submitted, while the item shows the item label. The table above ranks the difficulty level from the highest PEOU4 to the lowest BI2 shown in the Measure column. Information on the difficulty level of items makes it easy to identify difficult questions and easy questions.

To find out the level of suitability of the item (item fit), the meaning of which is in accordance with the ideal model of measurement, then we use item fit order, in the table below it appears that the item fit indicator for all items is outfit means square $(0.5<\mathrm{MNSQ}<1,5), \mathrm{Z}$-Standard Outfit $(-2.0$ 
In the figure above in the aspect of reliability with values of 0.86 and 0.89 that the value produces Good value for the respondent's data so that the software is good to use

\section{Measurement of Item Reliability}

The figure below explains the measurement of reliability of items

\begin{tabular}{|c|c|c|c|c|c|c|c|c|c|c|c|c|c|}
\hline $\begin{array}{l}\text { ITRY } \\
\text { IMBER }\end{array}$ & $\begin{array}{l}\text { TOTAL } \\
\text { SCORE }\end{array}$ & $\begin{array}{l}\text { TOTAL } \\
\text { COUNT }\end{array}$ & MEASURE & $\begin{array}{c}\text { MODEL } \\
\text { S.E. }\end{array}$ & Q & ZST & $\begin{array}{l}\text { DUT } \\
\text { SQ }\end{array}$ & $\begin{array}{l}F I T \\
\text { ZS }\end{array}$ & CORR. & EXP. 1 & S\% & $\begin{array}{r}\text { MATCH } \\
\text { EXP\% }\end{array}$ & Item \\
\hline 15 & 218 & 69 & -.13 & .32 & 1.49 & $1.91 \mid 1$ & 1.69 & $\left.2.01\right|_{A} ^{A}$ & A. .57 & .671 & 81.8 & 81.61 & \\
\hline$x^{2}$ & 220 & 69 & $\therefore$ & $2 \mid$ & 1.62 & $\begin{array}{l}2.38 \mid 1 \\
2.1\end{array}$ & |1.17 & $.64 \mid \mathrm{B}$ & $\begin{array}{llll} & 0.52\end{array}$ & .66 & \begin{tabular}{|l|l|}
81.8 \\
\end{tabular} & $|1.3|$ & 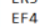 \\
\hline 20 & 216 & 69 & .08 & 32 & 1.40 & $1.61 \mid 1$ & 1.49 & 1.53 |c & c. .64 & .67 & 71.2 & 81.9 & ST 4 \\
\hline 19 & 218 & 69 & -.13 & 32 & 1.43 & $1.72 \mid 1$ & 1.47 & 1.48 iD & 0.70 & .67 & 68.2 & $81.6 \mid$ & ST3 \\
\hline 13 & 224 & 69 & -.76 & & 1.36 & $\left.1.59\right|_{1}$ & 1.40 & $1.33 j \mathrm{E}$ & E .66 & $.65 \mid$ & 75.8 & $80.7 \mid$ & ER1 \\
\hline 6 & 203 & 69 & 1.35 & 30| & 1.20 & $.97 \mid 1$ & |1.37 & $1.38 \mathrm{jF}_{\mathrm{F}}$ & F. .58 & .67 & 77.3 & 78.9 & EF2 \\
\hline 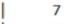 & 208 & 69 & .89 & $31 \mid$ & 1.24 & $\left.1.05\right|_{1}$ & 1.30 & $1.08 \mid \mathrm{G}$ & 6.64 & .67 & 75.8 & 80.9 & EF3 \\
\hline 17 & 224 & c. & -.76 & 2 & 1.23 & $\left.1.08\right|_{1}$ & 1.10 & $.42 \mid \mathrm{H}$ & Н. .68 & .65 & 78.8 & $80.7 \mid$ & ST1 \\
\hline . & 202 & 69 & 1.44 & 99| & & $-.15 \mid 1$ & 1.19 & $.78 \mid \mathrm{I}$ & I . 58 & $.67 \mid$ & 80.3 & 78.3 & 14 \\
\hline 3 & 215 & 69 & .18 & 2 & & $.75 \mid 1$ & 1.12 & .48|J & ].69 & $.67 \mid$ & 75.8 & $82.0 \mid$ & \\
\hline 9 & 225 & 69 & -.86 & .32 & .89 & $-.46 \mid$ & .77 & $-.77 \mid j$ & j.69 & .65 & 80.3 & 80.4 & ME1 \\
\hline 18 & & 65 & .49 & 年 & .75 & -1.09 & .71 & $-1.00 \mid \mathrm{i}$ & i. .66 & $.67 \mid$ & 81.8 & $81.6 \mid$ & ST2 \\
\hline 16 & 21 & 65 & $\begin{array}{l}-.13 \\
-.13\end{array}$ & .321 & .74 & -1.16 & .63 & -1.31 h & h. .67 & & $\begin{array}{l}89.4 \\
89.4\end{array}$ & 81.6 & ER4 \\
\hline 12 & 21 & 69 & .49 & $2 !$ & .73 & -1.19 & .65 & $-1.28 \mid \mathrm{g}$ & g. .63 & $.67 \mid$ & \begin{tabular}{|l|l|} 
& 91.8 \\
\end{tabular} & $\mid 1.6$ & ME4 \\
\hline 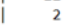 & 210 & 69 & .69 & 21 & .66 & -1.56 & | .72 & $-.99 \mid f$ & f. .75 & $.67 \mid$ & 90.9 & 81.2 & L2 \\
\hline 5 & 223 & 69 & -.66 & & .71 & -1.40 & .65 & -1.30 e & e. .73 & .66 & 84.8 & 80.9 & EF1 \\
\hline 14 & 230 & 69 & -1.35 & 1 & .70 & -1.70 & | . .67 . & $-1.28 j d$ & d .75 & $.63 \mid$ & 89.4 & $78.8 \mid$ & ER2 \\
\hline 11 & 214 & 69 & .25 & $.32 \mid$ & .58 & $-2.01 \mid$ & .40 . & $-2.54 \mid c$ & c. .80 & .67 & 87.9 & 81.9 & ME3 \\
\hline 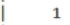 & 226 & 69 & -.96 & .32 & .48 & $-3.06 \mid$ & .43 & $-2.50 \mid \mathrm{b}$ & b . 78 & .65 & 92.4 & 80.1 . & L1 \\
\hline 10 & 215 & 69 & .18 & $.32 \mid$ & .45 & $-2.91 \mid$ & | . .37 & -2.72 |a & a. .73 & $.67 \mid$ & 93.9 & $82.0 \mid$ & ME2 2 \\
\hline & & & & & & & & & & & & 80 & \\
\hline & & & .74 & $.01 \mid$ & & $1.6 \mid$ & |. .40 & $1.5 \mid$ & & & 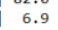 & $1.1 \mid$ & \\
\hline
\end{tabular}

Figure 11. Item Statistics

It can be seen in the table above that item question AU6, which contains one criterion that is not fit is Infit MeanSquare which is greater than 1.5

Determine reliability (variability)

To test data processing using Reliability, using Summary statistics consisting of:
1. Person reliability
2. Reliability of items
3. Alpha Cronbach

Value Person Reliability and Item Reability:

1) $<0.67$ results in Weak Value

2) $0.67-0.80$ Produces Fair Value

3) 0.81-0.90 Produces Good Value

4) $0.91-0.94$ Produces Very Good Value

5) .>0.94 Produces Special Value

Cronbach Alpha value (measuring Reliabiltas ie, interactions between person and item as a whole) viz
1) $<0.5$ yields a Poor value
2) 0.5-0.6 Produce Bad Value
3) 0.6-0.7 Produce Fair Value
4) 0.7 - 0.8 Produces Good Value
5) 0.8 Produces Very Good Value.

Measurement of person reliability

The figure below explains the measurement of person reliability

SUMMARY OF 66 MEASURED (NON-EXTREME) Person

\begin{tabular}{|c|c|c|c|c|c|c|c|c|c|}
\hline & \multicolumn{2}{|l|}{ TOTAL } & & \multicolumn{2}{|l|}{ MODEL } & \multicolumn{2}{|c|}{ INFIT } & \multicolumn{2}{|c|}{ OUTFIT } \\
\hline & SCORE & COUNT & MEASURE & S.E. & & MNSQ & ZSTD & MNSQ & ZSTD \\
\hline MEAN & 62.0 & 20.0 & 2.64 & .60 & & .97 & -.28 & .97 & -.31 \\
\hline SEM & .7 & .0 & .22 & .01 & & .09 & .19 & .10 & .19 \\
\hline P.SD & 6.0 & .0 & 1.80 & .08 & & .76 & 1.52 & .84 & 1.50 \\
\hline S.SD & 6.1 & .0 & 1.82 & .08 & & .76 & 1.53 & .84 & 1.51 \\
\hline MAX. & 78.0 & 20.0 & 7.40 & .76 & & 3.80 & 4.84 & 4.37 & 3.62 \\
\hline MIN. & 43.0 & 20.0 & -2.02 & .40 & & .06 & -2.86 & .05 & -2.85 \\
\hline REAL $\mathrm{R}$ & .68 & TRUE SD & $1.67 \mathrm{SEF}$ & ARATION & 2.48 & 3 Pers & son RE & IABILITY & Y .86 \\
\hline IODEL RMS & .60 & TRUE SD & 1.70 SEP & ARATION & 2.83 & & Son REL & IABILITY & Y $\quad .89$ \\
\hline
\end{tabular}

Figure 12. Summary statistics

\begin{tabular}{|c|c|c|c|c|c|c|c|c|c|c|c|}
\hline & \multicolumn{3}{|c|}{ TOTAL } & \multicolumn{4}{|c|}{ MODEL } & \multicolumn{2}{|c|}{ INFIT } & \multicolumn{2}{|c|}{ OUTFIT } \\
\hline & & & COUNT & MEASU & URE & S.E. & & MNSQ & ZSTD & MNSQ & ZSTD \\
\hline MEAN & & & 69.0 & & .00 & .32 & & .99 & -.18 & .97 & -.23 \\
\hline SEM & & & .0 & & 17 & .00 & & .08 & .38 & .09 & .34 \\
\hline P.SD & & 3 & .0 & & .74 & .01 & & .35 & 1.64 & .40 & 1.47 \\
\hline S.SD & & & .0 & & .76 & .01 & & .36 & 1.68 & .41 & 1.51 \\
\hline MAX. & & & 69.0 & & .44 & .32 & & 1.62 & 2.38 & 1.69 & 2.01 \\
\hline MIN. & & & 69.0 & & .35 & .29 & & .45 & -3.06 & .37 & -2.72 \\
\hline \multicolumn{2}{|c|}{ REAL RMSE } & 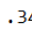 & TRUE SD & \multicolumn{3}{|c|}{.66 SEPARATION } & 1.93 & Ite & \multicolumn{2}{|c|}{ RELIABILITY } & .79 \\
\hline |MODEL & & .32 & TRUE SD & .67 & SEP & ATION & 2.12 & Ite & & ABILITY & .82 \\
\hline \multicolumn{4}{|c|}{ S.E. OF Item MEAN $=.17$} & & & & & & & & \\
\hline
\end{tabular}

Figure 13. Measurement of item reliability

Figure 13. Describes the measurement of item reliability having a value of 0.74 resulting in a pretty good value and 0.78 producing a enough good value.

\section{Measurement of Cronbach alpha}

The figure below explains the measurement of Cronbach alpha

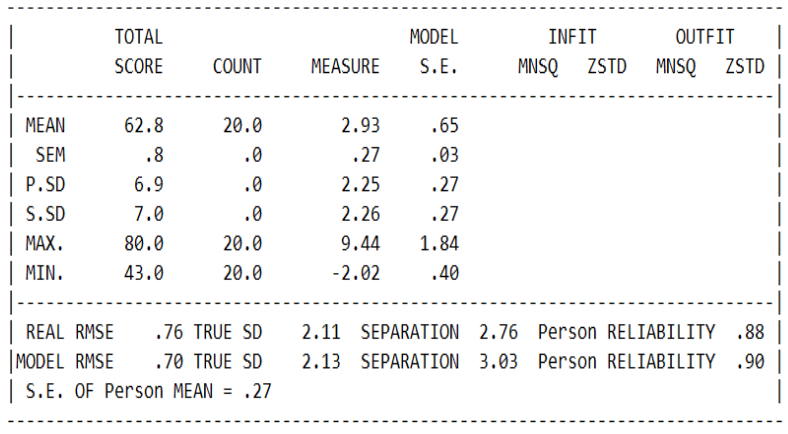

Person RAW SCORE-TO-MEASURE CORRELATION $=.99$

CRONBACH ALPHA (KR-20) Person RAW SCORE "TEST" RELIABILITY $=.94$ SEM $=1.75$

Figure 14. Summary statistics

In the figure above the Cronbach alpha index also produces a Cronbach Alpha value producing a value of 0.94 (Cronbach Alpha value ().

\section{Determination of sample size}

Rasch Modeling: determination of sample size based on measurement accuracy (1.0 logit scale or 0.5 logit); confidence level $(95 \%$ or $99 \%)$ 
Table 1. Determination of Sample Size

\begin{tabular}{|l|l|l|l|}
\hline Kalibrasi Aitem Stabil dalam & Tingkat Kepercayaan & Kisaran Sampel & Ukuran Sampel \\
\hline \pm 1 logit & $95 \%$ & $16-36$ & 30 \\
\hline \pm 1 logit & $99 \%$ & $27-61$ & 50 \\
\hline $\pm 0,5$ logit & $95 \%$ & $64-144$ & 100 \\
\hline $\pm 0,5$ logit & $99 \%$ & $108-243$ & 150 \\
\hline
\end{tabular}

(Source: Linacre, 1994. Sampel Sample Size and Item Calibration Stability. Rasch Measurement Transactions, 7: 4 p.328).[12] The table below shows the measurement of sample size using the Item Measure table based on the measurement accuracy (scale 1.0 logit or 0.5 logit); confidence level (95\%) Using 69 Respondent

\section{Category Probabilities Or Probabilty Curva}

In the curve below shows if value 4 is very agree, while value 3 is agree, value 2 indicates value disagree, while value 1 is strongly disagree can be seen the following probability curve

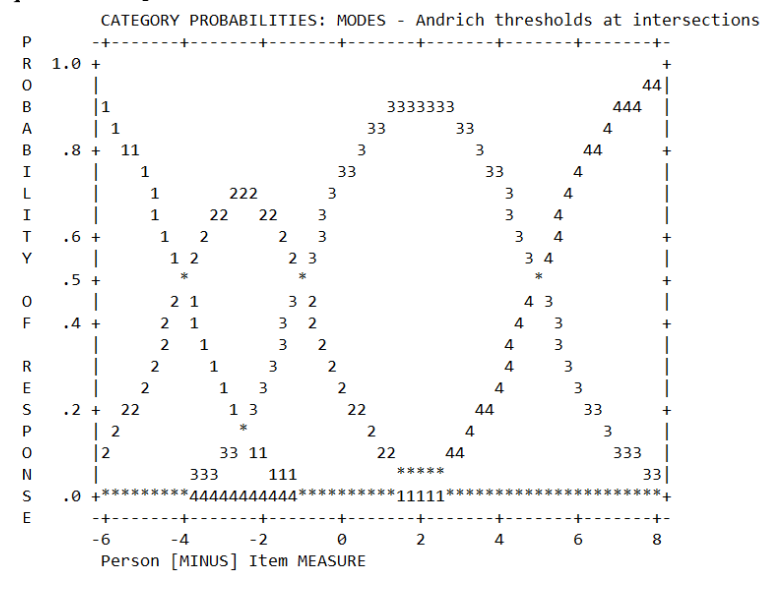

Figure 15. Category Probabilities

In the table above the respondents answered more agreed to this software, then the value of 4 strongly agreed, while the value 3 above was the respondent agreed.

\section{CONCLUSION}

Based on research that has been done, it can be concluded as follows:

1. Limitation of this research to build Androidbased software that consists of tourist objects, public places and culinary places in Palembang using the UML (Unified Modeling Language in Palembang city)

2. Calculate the level of user satisfaction with this program using the metrics used for TAM (Techn ology Acceptance Model), Perceived Use Facilit y (PEOU), Perceived Usefulness (PU), Attitude To Use (ATU), Cognitive Intention to Use (ITU, Actual System Use (ASU) with rasch model cal culation.
3. Testing Rasch model software to measure consisting of person reliability, reliability of items and Cronbach alpha

4. Questionnaires were compiled, circulated online and completed by 69 respondents.In addition to $t$ he Rasch test, a statistical inference experiment was used to measure the choice of attributes usin $\mathrm{g}$ the program "Ministep (Winsteps) Rasch." Fin dings: The methodology used in this analysis de monstrated good reliability and its validity matc hes the model expected

5. The data were collected by questionnaires, which were distributed online and completed by 69 respondents. In addition to the Rasch model, the preference of attributes was measured by a statistical inference test, using "Ministep (Winsteps) Rasch" software, . Findings: The instrument used in this study showed good reliability, and its validity fits the expected model.

6. The model uses 69 respondents, to test the data using the Rasch Model Testing with the Ministep application. In the aspect of reliability, for person reliability the value of 0.87 and 0.89 , produces a very good value. While for reliability items the value of 0.74 and 0.78 produces good value. while the Cronbach alpha index also produces a Cronbach Alpha value yields a value of 0.90 (produces a good value). Determination of sample size uses the Item Measure table based on the accuracy of confidence measurements (95\%)

\section{REFERENCES}

[1] H. N. Lengkong, A. A. E. Sinsuw, and A. S. . Lumenta, "Perancangan Penunjuk Rute Pada Kendaraan Pribadi Menggunakan Aplikasi Mobile GIS Berbasis Android Yang Terintegrasi Pada Google Maps," E-journal Tek. Elektro dan Komput., 2015.

[2] B. Yuwono, A. S. Aribowo, F. A. Setyawan, and P. T. Informatika, "Sistem Informasi Geografis Berbasis Android," J. Ilm. Tek. Inf., 2015.

[3] K. Anam and O. D. Hartono, “Aplikasi Pemandu Untuk Melakukan Pencarian objek Wisata Terdekat Berbasis GIS Android Dengan Algoritma Dijkstra," J-SAKTI (Jurnal Sains Komput. dan Inform., 2019.

[4] B. Yuwono, A. S. Aribowo, and F. A. Setyawan, "Sistem Informasi Geografis Berbasis 
[9] D. Kusnadi and J. Ma, "Electronic Government Pemberdayaan Pemerintahandan Potensi Kelurahan Pringsewu Selatan," J. TAM ( Technol. Accept. Model ), 2015.

[5] R. P. Agrarian, A. Suprayogi, and B. D. Yuwono, "Pembuatan Aplikasi Mobile Gis Berbasis Android Untuk Informasi Pariwisata Di Kabupaten Gunungkidul," J. Geod. Undip, 2015.

[6] C. Blut, T. Blut, and J. Blankenbach, "CityGML goes mobile: application of large 3D CityGML models on smartphones," Int. J. Digit. Earth, 2019.

[7] B. Setiawan, M. Panduwangi, and B. Sumintono, "A Rasch analysis of the community's preference for different attributes of Islamic banks in Indonesia," Int. J. Soc. Econ., 2018.

[8] M. Siri, Fitriyani, and A. Herliana, "Analisis Sikap Pengguna Paytren Menggunakan Technology Acceptance Model," J. Inform., 2017.
[10] C. Martin-Reinhold, J. Huerta, and C. Granell, "gvSIGDroid: An open source GIS solution for the Android platform," in WEBIST 2010 - Proceedings of the 6th International Conference on Web Information Systems and Technology, 2010.

[11] Wulandari and S. Aprilia, "Jurnal TAM ( Technology Acceptance Model) Volume 4 Juli 2015," Technol. Accept. Model, 2015.

[12] J. M. Linacre, "Sample Size and Item Calibration or Person Measure Stability," Rasch Meas. Trans., 1994. 